\title{
Frying edible vegetable oil quality from street-food vendors in a Metropolitan area in the Central Highlands of Mexico
}

\author{
Dora Luz PINZÓN-MARTINEZ ${ }^{1}$, Lilian Montes de OCA-ROSALES ${ }^{1}$, Argel FLORES-PRIMO², \\ Maria Dolores Mariezcurrena BERASAIN ${ }^{1 *}$ (D)
}

\begin{abstract}
Vegetable oil deterioration during frying is a health problem because of oil degradation compounds and recycled oil practices are related to disturb oil quality. Frying food street-vendors are an important part of endemic market type Tianguis at the Metropolitan areas in the Central Highlands of Mexico. The main objective of this research was to evaluate frying edible vegetable oil quality from frying by street-food vendors in a Metropolitan area in the Central Highlands of Mexico. A behaviour questionary registered fresh and recycling oil addition, frying temperature and method in real operation conditions for three working days. Free fatty acid, colour, $p$-Anisidine, peroxide, and TOTOX indexes were observed in the vendors by triplicate. Free fatty acids and peroxide values in two vendors exceeded the NMX-F-223-SCFI-2011 values. Physicochemical variables revealed oil oxidation deterioration. Not so high temperatures were registered, and continually fresh oil addition was suggested as mitigating or masking edible oil of thermal oxidation and its degradation agents during the observed time. Thermal oxidation could be lower than in controlled conditions as in many reports due to vendor operations studied as a real approximation that suggested less oil degradation. Present results could be evidence for government intervention in the regulation needs.
\end{abstract}

Keywords: edible vegetable oil; street vendors; frying temperatures; thermal oxidation.

Practical Application: Vegetable oils used are a good option for frying street-food vendors because of their less thermal oxidation presented and low price.

\section{Introduction}

Central Highlands of Mexico and metropolitan areas include Toluca and Mexico City with intense population areas and traffic between them because of several economic activities. Much research has shown some socioeconomic changes that have nutrimental affectations over children, teenagers, or adults from these areas, such as, obesity, diabetes mellitus, and cardiovascular diseases (Carrete \& Arroyo, 2014; García-González et al., 2015). Consumers' habits have been affected by that intense and daily people; together with, an increase in highly processed, fast food or food street vendors, which were observed. Toluca Valley and Mexico City shown some market type named Tianguis, which are temporary and informal street markets, where one of their higher sales is food. Food street vendors around America Latina are not always observed by health government authorities; therefore, obesogenic intake is freely sold (Carrete \& Arroyo, 2014; Heathcott, 2019; Lozano et al., 2019). Street fast food is a representative culinary endemic menu and an important viable food alternative for workers, who are not able to go home for lunch because of distance, lack of resources, or traveling time. On the other hand, Street-food vendor activity is a significant economic activity, especially for women with children or for low economical resources population. Mexican consumers appreciate food flavour, colour, texture, and smell; besides, their preference is directly associated with social, economic, or traditional aspects. Moreover, health care is not always one of the principals considered aspects (Heathcott, 2019; Lozano et al., 2019). Espinoza-Ortega et al. (2016) reported that behaviour and motivation diversities from Mexicans about food consumption are an open research field, which needs more academic and scientific reports. Demographic and sociocultural change phenomena had changed lifestyles such as food selection in many social strata in America Latina's countries. Many Mexican traditional fried food, includes corn culinary options such as quesadillas, sopes, tacos, or flautas including tortillas (flat cornbread) with several stews (Vegetables, Pork, or beef meat). Mexico State is one of the main corn (Zea mayz) producer organizations; clearly, traditional Street-food sold included it (Espinoza-Ortega et al., 2016). Nonetheless, the corn farmer diet has been increasingly replaced by high processed foods such as refined wheat flour, used for corn dogs or sausages sold; together with, low fruits or vegetable presence on diets. Long distances to get to job locations in Metropolitan areas and economic capacities influence their inhabitants, who spend many hours outside their homes over their food decisions (Moreno, 2013; Espinoza-Ortega et al., 2016; Lozano et al., 2019).

Fried food has emerged in modern life using edible vegetable oils. Frying is the most important and easiest food 
step preparation; besides, fat and oil give a unique flavour and palatability. Immersion frying includes hot oil $120-180{ }^{\circ} \mathrm{C}$ temperatures and heat is transferred from oil to food surface and into the core food by conduction. Crust formation due to temperature increase closer to oil temperature. This frying method offers colour, flavour, crispy texture, cooking speed, and energy efficiency. Oil and fried physicochemical food changes are toxic. Moisture, oxygen presence, free radicals, frying time and temperature, reuse oil practice, or some elements to initiate hydrolysis, polymerization or thermoxidation, of oil and lipids; hence, oil deterioration increases with the presence of compounds as peroxides or free fatty produced acids (Rivera et al., 2014; Mba, 2017; Rudzińska et al., 2018). Frying oil goes off and oxidative compounds formed affect not only the food produced but also the oil quality. Recycled oil practice and its relation to produce unwanted compounds, disturb oil quality and represent a potential human health risk factor due to the deterioration in products absorbed into fried products reducing its nutritional value (Naghshineh \& Mirhosseini, 2010; Hernández Becerra et al., 2014; Ganesan et al., 2018). Latin American countries have several edible vegetable oil degradation and nutritional value research to improve food-frying regulations, especially, in reusing vegetable oils practice, in small and medium businesses. In Mexico, a low social class population, cook using high oil quantities to "achieve a good food flavour". Middle and low social classes, where women work and no home cooking is done anymore, this increases their fried or fast-food consumption. Mexican traditional fried food (Tamales, tacos, flautas, pambazos) and fast food are affected in nutritional value by the frying process (Torres \& Rojas, 2018; Yu et al., 2018). Traditional and local fast food is a public health issue (Medina-Meza et al., 2011; Morales-Guerrero et al., 2015; Astudillo, 2018). Frying temperature control, time process, and food type are the most relevant variables; together with, oil renovation grade as the oil proportion added per hour to make up for oil lost into fried products (Tirado et al., 2012). Free fatty acids released, moisture, peroxide value, and anisidine index are the most used tests for frying vegetable oil deterioration estimation (Freire et al., 2013). In Mexico, there is no such monitoring programs for compliance with regulations on oil deterioration regulation, implemented to control traditional or fast fried food sold on commercial streets. Therefore, vegetable oil frying deterioration is a common risk factor, acquired for an important percentage in the population. The main objective of this research was to evaluate edible vegetable oils quality, during frying by street-food vendors in Metropolitan areas in the Central Highlands of Mexico area through a behaviour questionnaire, frying temperature registration $(\mathrm{T})$, free fatty acids (FFA), peroxide (PV), $p$-Anisidine (AV) and TOTOX (TX) values, colour index (CI) and fatty acid composition (FAC).

\section{Material and methods}

\subsection{Behaviour questionnaire}

Information about the most-produced Mexican traditional fried and fast-food frying procedures was obtained through an exploration questionnaire applied to four street frying food vendors. Type of food prepared, oil vegetable brand, type of utensils, frying method, new oil addition or oil re-used practices, frying temperature, and frying temperatures were observed for three consecutive working days.

\subsection{Material and sampling}

Four street frying vendors were studied. A thermocouple (HOBO U12 J, K, S, T Thermocouple Data Logger) was connected to the saucepan or food container at sampling time for temperature measurement. Oil samples for the consecutive workdays by triplicate were taken with a stainless-steel ladle to place hot oil in amber glass jars and stored at freezing conditions.

\subsection{Physiochemical analyses}

Free Fatty Acids determination (FFA)

Ca 5a-40 AOCS Free Acids in Crude and Refined Fats and Oils Methodology (Association of Official Analytical Chemists, 2009) was used, where oil samples denatured were titled with 0.1 M Sodium hydroxide (Merck, USA) and FFA calculations were estimated as oleic acid percentage.

Peroxide Value (PV), p-Anisidine Value ( $p-A V)$ and total oxidation (TOTOX) value (TX)

PV was determined using the AOCS Official Method Cd 8-53 (Association of Official Analytical Chemists, 2004) that is a methodology for all substances. The determination was calculated as meq $/ \mathrm{kg}$ oil that oxidizes the potassium iodide in the test and compounds produced are assumed as peroxides or fat oxidation similar products. $p-\mathrm{AV}$ was evaluated according to AOCS Official Method Cd 18-90 (Association of Official Analytical Chemists, 1997) to determine aldehydes amount (mainly, 2-alkenes and 2,4-dienals) in vegetable oils or animal fat or oil by reaction in an acetic acid solution, and $p$-anisidine produced was determined by $350 \mathrm{~nm}$ of absorbance. TX value was calculated from: TOTOX $=2 \mathrm{PV}+p-\mathrm{AV}$ (Rudzińska et al., 2018).

\section{Colour Index determination (CI)}

CI was according to AOCS Official Method Cc 13c-50 (Association of Official Analytical Chemists, 2017) with Chloroform-Methanol (Merck, USA) as solvent and spectrophotometric lectures at 460, 550,620 , and $670 \mathrm{~nm}$.

\section{Fatty Acid Composition analysis by gas chromatography (FAC)}

Fresh oil and frying oil samples fatty acid methyl esters (FAME) preparation and composition were evaluated as Libien Jiménez (2014) methodology in a Perkin Elmer Auto system XL GC with a flame ionization detector (FID), split/splitless injector, and a Supelco SP ${ }^{\mathrm{TM}}-2560$ capillary GC (100 m X $0.25 \mathrm{~mm}$, df $\left.0.20 \mu \mathrm{m}\right)$ Capillary Column. Carrier gas was He with a $25 \mathrm{~mL} / \mathrm{min}$ flow rate. Injector and detector temperatures were $200^{\circ} \mathrm{C}$. Supelco ${ }^{\circ}$ 37 Component FAME Mix (Merck, USA) was used as standard for C16:0, C18:2, C18:1, C18:3, and C18:0.

\subsection{Experimental design}

A 4X3 factorial design was performed in a $1 \%$ Variance Analysis (ANOVA). Four street frying vendors $\left(\mathrm{V}_{1}-\mathrm{V}_{4}\right.$ vendors $)$ were studied. Factor $A$ consisted of vendor conditions and factor $B$ were the three workdays observed consequently. Statistical differences found were analysed by a Tukey $5 \%$ media test. 
Answer variables were frying temperature registration $(\mathrm{T})$, free fatty acids (FFA), peroxide (PV), p-Anisidine (AV), and TOTOX (TX) values, colour index (CI), and fatty acid composition (FAC). All tests were made by triplicate. Statistical analyses were done with the Software SAS 9.0 (SAS Institute, 2006).

\section{Results and discussion}

\subsection{Behaviour questionnaire and frying temperatures}

High processed wheat flour or obesogenic kind food was found as fast food sold in $V_{1}, V_{2}$, and $V_{3}$ (potatoes chips, French fries, corn dog, and sausages). French fries were washed, cut, soaked in water, and drained until their use; nevertheless, fried potatoes were not soaked. Traditional Mexican food found, were chicharron, pambazos, flautas (large fried tacos), and stews quesadillas, were only observed in $\mathrm{V}_{4}$ vendor. Potatoes chips, French fries, corn dogs and sausages, were the fast-food sold in $V_{1}, V_{2}$, and $V_{3}$. Traditional fried Mexican food such as chicharron, pambazos, flautas (large fried tacos), and stews quesadillas, were only observed in $\mathrm{V}_{4}$ vendor. All vendors reported to use the same edible vegetable oil consisted of Brassica sp. (rapeseed), Glycine max (soy), Helianthus annuus (sunflower), and Carthamus sp. (safflower) oil mix; then vegetable oil used was not a variable by street vendors studied. Frying process usually started with clean stainless-steel containers or pots. Immersion was the most used frying method applied (15-20 L initial oil volume) according to the type of food prepared. $\mathrm{V}_{4}$ vendor used superficial frying ( $0.5 \mathrm{~L}$ initial oil volume). $\mathrm{V}_{1}$ and $\mathrm{V}_{4}$ vendors begun their workday using new oil and the rest of the commercial establishments $\left(\mathrm{V}_{2}\right.$ and $\left.\mathrm{V}_{3}\right)$ started with oil re-used (used for at least one week). Most of the vendors occasionally add fresh oil, except for $\mathrm{V}_{4}$ vendor, who added it constantly. All street vendors frying temperature values were according to usual frying temperatures $\left(120-180^{\circ} \mathrm{C}\right)$ (Table 1$)$. Frying temperatures were unaffected by the vendor's operation conditions or during the workdays registered. These observed temperatures were lower to several authors, and do not exceed $200{ }^{\circ} \mathrm{C}$ as several authors reported, where more oil unwanted reactions are achieved. No $200^{\circ} \mathrm{C}$ higher temperatures observed were a putative prevention of an extremely accelerated thermal oxidation reaction in the present research (Gadiraju et al., 2015; Oke et al., 2018; Astudillo, 2018). Unaffected frying temperatures by the vendor's operation (Table 1) was suggested because of the common fresh oil addition observed (Park \& Kim, 2016; Oke et al., 2018). These results were obtained in three working days, which reflected the real operation conditions of Tianguis street-vendors.

\subsection{Physicochemical analyses}

In factor A street frying vendors, significant differences $(P \geq 0.01)$ were found in FFA, PV, TX, and C; together with, $\mathrm{C} 16: 0, \mathrm{C} 18: 0, \mathrm{C} 18: 1, \mathrm{C} 18: 2$, and $\mathrm{C} 18: 3$ fatty acid. There were no notable differences $(P \geq 0.01)$ for $p$-AV and temperature variables. In the workday factor (Factor $\mathrm{B}$ ), notable differences $(P \geq 0.01)$ were observed only for $\mathrm{PV}, \mathrm{C}, \mathrm{TX}$, and $\mathrm{C} 18: 0$ variables. The interaction factor showed notable differences $(P \geq 0.01)$ for $\mathrm{C}$ and $\mathrm{TX}$ variables.

\subsection{Free Fatty Acids determination (FFA), peroxide value, $p$-Anisidine ( $p-A V)$, and TX values}

For factor $\mathrm{A}$ the highest $\mathrm{FFA}$ value was found at $\mathrm{V}_{3}$ vendor, followed by $V_{2}(0.80$ and 0.41 , respectably) (Table 1$)$. No re-used oil was registered in the lower FFA values from $\mathrm{V}_{1}$ and $\mathrm{V}_{4}$ vendors and a frequently replenishing of frying oil were used, where lower FFA values were observed. All vendors presented FFA values higher than vegetable oil Mexican Norm (NMX-F-223-SCFI-2011) $(0.05 \%)$. Higher FFA has been shown in other street vendors research, where higher frying temperatures $\left(\geq 170{ }^{\circ} \mathrm{C}\right)$ were used than in the present project reported. Putative frying temperatures observed were able to break $\mathrm{C}-\mathrm{C}$ or $\mathrm{C}-\mathrm{H}$ bonds from oil triglycerides; even though, FFA values were not as high as in other reports (Rudzińska et al., 2018; Chinaza et al., 2018). The frequently replenishing of frying oil $\mathrm{V}_{1}$ and $\mathrm{V}_{4}$ vendors observed could explain the lower FFA values, presented in those street vendors due to a slower hydrolysis is related to fresh oil addition (Rivera et al., 2014; Mba, 2017).

Peroxide compounds are oil deterioration evidence, and they are caused by rancid odor and flavour originated by oxygen action over the double bonds and more complex radicals (aldehydes and ketones) are formed later. For factor A, the PV was higher at $\mathrm{V}_{4}$ vendor $(7.0 \mathrm{meq} / \mathrm{kg}$ oil $)$ and all the vendors exceeded the NMX-F-223-SCFI-2011 (Mexico, 2001) maximum value (2.0 meq $/ \mathrm{kg}$ oil) (Table 1). All the vendors exceeded the NMX peroxide maximum value $(2.0 \mathrm{meq} / \mathrm{kg}$ oil) (Table 1$)$, especially $\mathrm{V}_{4}$ vendor. Vendor different operation conditions (Factor A) have a negative effect over the oil deterioration by peroxide compounds formation and as evidence for oil deterioration and a decrease door and flavour oil qualities. The lowest PV on the third-day values (Table 2) could be explained because thermal oxidation and speed reactions are fast and produce primarily oxidation compounds, which are registered by PV values. Then, organic formed compounds are highly reactive and propagate a chain reaction of lipid peroxidation; therefore, hydroperoxides formed are no stable during the frying process

Table 1. Physicochemical parameters and FAC means from frying oils by vendor conditions.

\begin{tabular}{clllllllllll}
\hline Vendor & FFA & PV & $p$-AV & CI & TX & C 16:0 & C 18:2 & C 18:1 & C 18:3 & C $18: 0$ & $\mathrm{~T}^{\circ} \mathrm{C}$ \\
\hline $\mathrm{V}_{1}$ & $0.27 \mathrm{c}$ & $4.88 \mathrm{~b}$ & $0.44 \mathrm{ab}$ & $1.93 \mathrm{~d}$ & $11.27 \mathrm{~b}$ & $7.95 \mathrm{c}$ & $27.59 \mathrm{~b}$ & $66.17 \mathrm{a}$ & $1.00 \mathrm{a}$ & $4.09 \mathrm{~b}$ & 140.50 \\
$\mathrm{~V}_{2}$ & $0.41 \mathrm{~b}$ & $5.44 \mathrm{~b}$ & $0.45 \mathrm{ab}$ & $31.98 \mathrm{a}$ & $10.23 \mathrm{~b}$ & $10.70 \mathrm{~b}$ & $21.47 \mathrm{c}$ & $64.32 \mathrm{a}$ & $0.843 \mathrm{ab}$ & $5.13 \mathrm{a}$ & 147.20 \\
$\mathrm{~V}_{3}$ & $0.80 \mathrm{a}$ & $5.11 \mathrm{~b}$ & $0.56 \mathrm{a}$ & $11.64 \mathrm{~b}$ & $10.13 \mathrm{~b}$ & $13.13 \mathrm{a}$ & $37.96 \mathrm{a}$ & $40.21 \mathrm{~b}$ & $0.68 \mathrm{~b}$ & $4.61 \mathrm{ab}$ & 119.00 \\
$\mathrm{~V}_{4}$ & $0.27 \mathrm{c}$ & $7.00 \mathrm{a}$ & $0.39 \mathrm{~b}$ & $4.33 \mathrm{c}$ & $14.87 \mathrm{a}$ & $8.81 \mathrm{c}$ & $26.34 \mathrm{bc}$ & $63.10 \mathrm{a}$ & $1.018 \mathrm{a}$ & $3.81 \mathrm{~b}$ & 150.41 \\
$\mathrm{LSD}(0.05)$ & 0.04 & 1.26 & 0.16 & 2.31 & 2.64 & 1.13 & 5.67 & 4.31 & 0.22 & 0.87 & 34.04 \\
\hline
\end{tabular}

Different letters between columns mean significant differences. $\mathrm{FFA}=$ free fatty acids; $\mathrm{PV}=$ peroxide values; $p$-AV= $p$-Anisidine; $\mathrm{CI}=$ colour index; $\mathrm{TX}=\mathrm{TOTOX}$ values; $\mathrm{LSD}=\mathrm{Least}$ significant difference; $\mathrm{T}=$ Temperature. 
Table 2. Physicochemical parameters and fatty acids composition mean from frying oils by three workdays consecutively.

\begin{tabular}{lllllcccccccc}
\hline \multicolumn{1}{c}{ Workday } & FFA & PV & $p$-AV & CI & TX & C 16:0 & C 18:2 & C 18:1 & $\mathrm{C} 18: 3^{2}$ & $\mathrm{C} 18: 0^{\circ}{ }^{\circ} \mathrm{C}$ \\
\hline 1 & 0.44 & $6.25 \mathrm{a}$ & $0.42 \mathrm{~b}$ & $11.29 \mathrm{~b}$ & $11.92 \mathrm{~b}$ & 10.64 & 28.56 & 59.45 & 0.98 & $5.18 \mathrm{a}$ & 132.50 \\
2 & 0.44 & $6.62 \mathrm{a}$ & $0.58 \mathrm{a}$ & $14.69 \mathrm{a}$ & $14.23 \mathrm{a}$ & 9.92 & 27.65 & 58.52 & 0.80 & $3.88 \mathrm{~b}$ & 147.20 \\
3 & 0.44 & $3.95 \mathrm{~b}$ & $0.38 \mathrm{~b}$ & $11.17 \mathrm{~b}$ & $8.69 \mathrm{c}$ & 9.88 & 28.81 & 57.38 & 0.86 & $4.16 \mathrm{~b}$ & 138.20 \\
LSD $(0.05)$ & 0.03 & 1.09 & 0.14 & 2.00 & 2.28 & 0.98 & 4.91 & 3.73 & 0.19 & 0.75 & 29.48 \\
\hline
\end{tabular}

Different letters between columns mean significant differences. $\mathrm{FFA}=$ free fatty acids; $\mathrm{PV}=$ peroxide values; $p$ - $\mathrm{AV}=p$-Anisidine; $\mathrm{CI}=$ colour index; $\mathrm{TX}=\mathrm{TOTOX}$ values; $\mathrm{LSD}=\mathrm{Least}$ significant difference; $\mathrm{T}=$ Temperature.

and originated alkoxy radicals and hydroxy radicals decreasing PV values as a result. Several authors proposed it as the decrease PV reason, during long frying periods. $\mathrm{V}_{4}$ conditions as the type of food processed, reused oil practice, and oil addition or oil initial quantity could affect speed oil oxidation (Mba, 2017; Oke et al., 2018; Rudzińska et al., 2018). Prepared food could present those toxic, and not-health related chemical compounds (Marinova et al., 2012; Park \& Kim, 2016). During the workday, PV resulted lower on the third day (Factor B) (Table 2).

Secondary oxidation compounds (Aldehydes) measured by $p-\mathrm{AV}$ are reported as an oil thermostability estimation and a fast and less expensive frying oil deterioration determination for small producers. $p$ - AV values presented no differences either vendors or working day factors (Table 1). Thermostability estimation by $p$-AV (Table 1 ) was unaffected by vendor operation conditions. Fresh oil $p$-AV values reported by Rudzińska et al. (2018) resulted in the present results (1.0-4.3). This parameter has been considered as an available oil frying quality estimation for second oxidation compounds, aldehydes (2-alkenals, and 2,4-alkadienals). Those compounds are related to oil odor negative sensory alterations as burn or rancid attributes ( $\mathrm{Mba}$, 2017; Rudzińska et al., 2018). TOTOX values are a more complete oxidation approximation, which considers $\mathrm{PV}$ and $p$-AV. For Factor, A TX values were higher than $V_{4}$ vendor results and suggested primary and secondary oxidation during frying (Table 1) because of its estimation value. $V_{4}$ with the highest putative oxidation estimation was the only vendor with superficial frying operation conditions, which was different from the other vendors. In the $2^{\text {nd }}$ workday, the highest TX value was achieved, and it decreased later. The interaction factor indicated that vendor conditions and workdays studies affected oil frying oxidation. The lowest TX values were observed on the third working day studied. The most complete oxidation estimation is done by TOTOX value that includes $\mathrm{PV}$ and $p$-AV. For vendors operation conditions (Factor A) TX values from $V_{4}$ vendor resulted higher and were suggested because of primary oxidation presence (Table 1). This value for working days (Factor B) presented a decrease after the $2^{\text {nd }}$ workday; moreover, it has been presented that vendor conditions and workdays interaction affected oil frying oxidation. Third day lowest TX values observed could be originated by fresh oil addition (Table 2). Most of the vendor's conditions suggested secondary oxidation. However, $p$-VA, $\mathrm{PV}$, and TX value increase from others research during frying times at $170-200^{\circ} \mathrm{C}$ were without fresh oil addition; accordingly, that particularity putative situation could explain the not so high present results for those oil estimations (Rudzińska et al., 2018; Astudillo, 2018; Godswill et al., 2018). Aladedunye and Przybylski (2013) explained a $p$-AV reduction was preceded by fresh oil addition. Nevertheless, primary oxidation compounds in the first frying hours are degraded producing epoxides as secondary oxidation results. $p$-AV present results were not affected and were similar to fresh oil values, whereas TX values presented could be explained for. Nonetheless, fresh oil addition could be an improve odour oil frying and a mitigating oil race degradation chemical compounds production that at the same time could mask its presence (Freire et al., 2013). It is important to point out that frying is a transfer mass phenomenon between food and oil; therefore, no oxidation compounds into fried food cannot be confirmed (Mba, 2017; Flores et al., 2018).

\subsection{Colour Index (CI)}

$\mathrm{CI}$ was affected by vendor operation conditions. $\mathrm{V}_{2}$ vendor presented the darkest colour (31.98) (Table 1). CI increased on $2^{\text {nd }}$ workday and decreased on the last studied day (Table 2). The interaction factor suggested than vendor operation conditions during the period studied affected frying oil darkening. CI increase is originated from irreversible physical damage related to oil degradation processes. Excessive oil frying deterioration indicated by darkening is a useful oil quality indicator for some authors, but other authors reported that is not always correlated to frying oil quality. FFA produced, amino-carbonyl reaction between oxidized oil by heat, amino acids from food processed, among other circumstances is associated with colour alterations while frying. French or slice potatoes are cited as intense Maillard reaction foods with intense colouring compound formation and could be the reason for CI values from vendors 1 to 3 , which processed these kinds of food. Fresh oil addition was suggested for the CI decrease (Table 2) observed for the third working day (Freire et al., 2013; Aladedunye \& Przybylski, 2013; Rudzińska et al., 2018).

\subsection{Fatty Acid Composition analysis by gas chromatography (FAC)}

C16:0, C18:0, C18:1, C18:2, and C18:3 fatty acid profiles were affected by vendor conditions. For working days only C18:0 was affected. Saturated fatty acid studied (Stearic and palmitic acids) shown higher values in $\mathrm{V}_{3}$ and $\mathrm{V}_{2}$ vendors, especially $\mathrm{V}_{3}$ vendor (5.13-10.13\%) than in the rest of the vendors (3.81-8.81\%). C18:1 presented the highest percentages values in $\mathrm{V} 1$ vendor (66.17\%); while $\mathrm{V}_{3}$ vendor presented the lowest value (Table 1). As it was expected as more unsaturated the fatty acid was, the less percentages values were observed. $\mathrm{V}_{4}$ and $\mathrm{V}_{1}$ presented the C18:3 lowest percentages (Table 1). Stearic acid was the only fatty acid affected by workdays (Table 2). C18:2 and C18:1 fatty acids were unaffected by Workday's factor (Table 2). Temperatures 
reported during the workdays $\left(132.50-147.22^{\circ} \mathrm{C}\right)$ (Table 2) did not present significant differences $(p \geq 0.01$ ) by both factors.

FAC changes during frying are a useful thermal-oxidative method assessment; furthermore, C18:2 acid is often an oil degradation degree indicator. Fatty acid profiles in the present research were affected by vendor condition operations. C18:0 fatty acid was the only one affected by the working day factor; together with, the constant fresh oil addition could not allow to visualize a real FAC degradation change. Unsaturated fatty acids presented higher degradation than saturated fatty acids as in similar reports, and as it was expected (Table 2). $\mathrm{V}_{4}$ vendor used a superficial frying method, which demands less total oil quantity. All vendors used the same edible vegetable oil, a mixture of four components. Of which, only two (Soy and rapeseed oils) contained 18:3 fatty acid, and the rest, contained high concentrations of linoleic acid, safflower especially. C18:2 and C18:1 suggested similar results than other reports, as polyunsaturated fatty acids (PUFA) more sensitive to thermal oxidation. Park \& Kim (2016) suggested the saturated fatty acids incorporation from the fried foods to frying oils; thus, all vendor food processed, and oil added could explain the variability of the present results. Edible vegetable oils are mentioned as good frying oil options preceded by palm, coconut, or their blends with several single vegetable oils (Osawa \& Gonçalves, 2012; Tarmizi \& Ismail, 2014). C18:2 and C18:1 fatty acids were unaffected by Workday's factor, which could be originated by the migration from food products into oil or by fresh oil addition, as it was explained in other reports; even though many researchers have proved PUFA double bonds sensibility to thermal degradation (Sharoba \& Ramadan, 2012; Park \& Kim, 2016) (Table 2). Even though the high temperatures reported in other research $\left(170-190^{\circ} \mathrm{C}\right)$ were not reached in the present research and Oleic and linoleic fatty acids decreased after $\geq 2$ days of frying. Then, not high temperatures applied, and oil addition were putative factors for no significant differences $(P \leq 0.01)$ on FAC during the passing time studied (Christy, 2017; Flores et al., 2018; Yu et al., 2018). The second workday stearic acid decrease is difficult to explain because of several physicochemical changes during deep-frying as oil absorption by food and fatty acid transfer into the oil (Torres \& Rojas, 2018; Dobarganes \& Márquez-Ruiz, 2015; Sayon-Orea et al., 2015). It should be mentioned that the present research has shown real food vendor condition operations, identified in Mexican traditional markets (Tianguis), which are a common food offer practice in Metropolitan areas in Mexico (Espinoza-Ortega et al., 2016; Heathcott, 2019; Lozano et al., 2019). These kinds of vendors workday's real conditions effects were studied; otherwise, the related reports based on controlled frying conditions (Temperature or one kind of food processed, mainly) presented higher fatty acid oil deterioration degrees, but at higher temperatures and with no edible vegetable oil mix (Marinova et al., 2012).

\section{Conclusions}

Edible vegetable oils quality from street-food vendors in a Metropolitan area in the Central Highlands of Mexico, parameters of frying temperature, free fatty acid determination, peroxide, $p$-Anisidine, and TOTOX, colour index values, and fatty acid composition revealed oil hydrolysis, oxidation, and deterioration. Primary oxidation and different fatty acid composition during frying found suggested oil degradation evidence, whereas less second oxidation observed. Some quality values studied exceed Mexican Norms specifications. Although, the not so high frying temperatures and oil addition practice could suggest lower oil degradations; indeed, these could be mitigating and masking agents at the same time. Edible vegetable mix oil used presented less fatty acid degradation than soy oils or rich fatty acid oils as other oil blends. Traditional and fast food fried from street-food vendors are a Mexican traditional food option from this Central High Metropolitan area necessities that could present chemical oil oxidation compounds as a health risk factor available for free sale. Government extensive health program intervention based on an extensive transdisciplinary scientific research evidence is urgently needed to not alter that socioeconomic street vendor structure. This paper presented real frying operation conditions in street food vendors where there are no controlled variables and all of them are according to the working day necessities.

\section{Funding}

This paper research wants to thank to the National Council of Science and Technology (CONACyT), Mexico because of the granted scholarship to carry out the master's degree studies done by one of the authors.

\section{Acknowledgements}

The authors would like to thank Universidad Autonoma del Estado de Mexico due to research support given.

\section{References}

Aladedunye, F., \& Przybylski, R. (2013). Frying stability of high oleic sunflower oils as affected by composition of tocopherol isomers and linoleic acid content. Food Chemistry, 141(3), 2373-2378. http:// dx.doi.org/10.1016/j.foodchem.2013.05.061. PMid:23870970.

Association of Official Analytical Chemists - AOCS. (1997).p-Anisidine value (Method Cd 18-90). Illinois: AOAC.

Association of Official Analytical Chemists - AOCS. (2004). Peroxide value-acetic acid-chloroform method (Method Cd 8-53). Illinois: AOAC.

Association of Official Analytical Chemists - AOCS. (2009). Free fatty acids in crude and refined fats and oils (Method Ca 5a-40). Illinois: AOAC.

Association of Official Analytical Chemists - AOCS. (2017). Colour of fats and oils, spectrophotometric (Method Cc 13c-50). Illinois: AOAC.

Astudillo, R. G. C. (2018). Edible vegetable oil degradation evaluation during french fries' potatoes. Cuenca, Ecuador: Universidad del Azuay.

Carrete, L., \& Arroyo, P. (2014). Social marketing to improve healthy dietary decisions: insights from a qualitative study in Mexico. Qualitative Market Research, 17(3), 239-263. http://dx.doi.org/10.1108/ QMR-11-2011-0023.

Christy, A. A. (2017). Changes in unsaturated fatty acid profiles of some vegetable oils during frying at medium frying temperature. Journal of Chemical and Pharmaceutical Research, 10, 223-226.

Dobarganes, C., \& Márquez-Ruiz, G. (2015). Possible adverse effects of frying with vegetable oils. British Journal of Nutrition, 113(S2), S49-S57. http://dx.doi.org/10.1017/S0007114514002347. PMid:26148922. 
Espinoza-Ortega, A., Martínez-García, C. G., Thomé-Ortiz, H., \& Vizcarra-Bordi, I. (2016). Motives for food choice of consumers in Central México. British Food Journal, 118(11), 2744-2760. http:// dx.doi.org/10.1108/BFJ-04-2016-0143.

Flores, M., Meyer, L., Orellana, S., Saravia, C., Galdames, C., \& PerezCamino, M. C. (2018). Quality of lipid fractions in deep-fried foods from street vendors in chile. Journal of Food Quality, 2018, 1-8. http://dx.doi.org/10.1155/2018/7878439.

Freire, P. C. M, Mancini-Filho, J., \& Pinto de Castro, T. A. (2013). Major physical and chemical changes in oils and fats used for deep frying: regulation and effects on health. Revista de Nutrição, 26(3), 353-358.

Gadiraju, T. V., Patel, Y., Gaziano, J. M., \& Djoussé, L. (2015). Fried food consumption and cardiovascular health: a review of current evidence. Nutrients, 7(10), 8424-8430. http://dx.doi.org/10.3390/ nu7105404. PMid:26457715.

Ganesan, K., Sukalingam, K., \& Xu, B. (2018). Impact of consumption and cooking manners of vegetable oils on cardiovascular diseases: critical review. Trends in Food Science \& Technology, 71, 132-154. http://dx.doi.org/10.1016/j.tifs.2017.11.003.

García-González, M. D., Adame-Martínez, A., \& Sánchez-Nájera, R. M. (2015). Growth of the metropolitan area of Toluca: Calimaya city hall, México. Quivera, 17(1), 35-53.

Godswill, A. C., Amagwula, I. O., Victory, I. S., \& Isiaga, G. A. (2018). Effects of repeated deep frying on refractive index and peroxide value of selected vegetable oils. International Journal of Advanced Science and Technology, 4, 106-110.

Heathcott, J. (2019). Architecture, urban form, and assemblage aesthetics in Mexico City' street markets. Archnet-IJAR, 13(1), 72-92.

Hernández Becerra, J. A., Ochoa Flores, A. A., Valerio-Alfaro, G., SotoRodríguez, I., Rodríguez-Estrada, M. T., \& García, H. S. (2014). Cholesterol oxidation and astaxanthin degradation in shrimp during sun drying and storage. Food Chemistry, 145, 832-839. http://dx.doi. org/10.1016/j.foodchem.2013.08.098. PMid:24128553.

Libien Jiménez, Y. A. M. E. L. (2014). Effect of the addition of organic selenium in the diet of finishing sheep on the shelf life of the meat (Ph.D. thesis). Universidad Autónoma del Estado de México, Toluca.

Lozano, D., Martínez, A., \& Montoya, B. J. (2019). The significant substrate of eating practices, in the context of recent policies in the face of excess weight in Mexico. Revista Latinoamericana Edu Est Intercultura, 3(2), 114-127.

Marinova, E. M., Seizova, K. A., Totseva, I. R., Panayotova, S. S., Marekov, I. N., \& Momchilova, S. M. (2012). Oxidative changes in some vegetable oils during heating at frying temperature. Bulgarian Chemical Communications, 44(1), 57-63.

Mba, O. (2017). Deep-fat frying characteristics of blends of palm and canola oils (Ph.D. thesis). McGill University, Montréal.

Medina-Meza, I. G., Rodríguez-Estrada, M. T., Lercker, G., SotoRodríguez, I., \& García, H. S. (2011). Unusual oxidative pattern in thermo-oxidation of dry films of cholesterol. Revista Mexicana de Ingeniería Química, 10(1), 47-57.

Mexico, Norma Oficial Mexicana. (2001). Alimentos: aceite vegetal comestible - especificaciones (NMX-F-223-SCFI-2011). Ciudad de Mexico: NOM.
Morales-Guerrero, J. C., García-Zepeda, R. A., Ruiz-Jiménez, S., RosasRomero, M. J., Salas-Velázquez, V., \& Morales-Ravelo, C. (2015). Chemical analysis of typical cooked foods of the states of Puebla and Tlaxcala, México. Agrociencia, 49(7), 749-758.

Moreno, M. (2013). Maize in the structure of the food consumption of the mothers of the family and the nutritional status of its members, in two communities that produce native maize in the State of Mexico (Ph.D. thesis). Universidad Autónoma del Estado de México, Toluca.

Naghshineh, M., \& Mirhosseini, H. (2010). Effects of frying condition on physicochemical properties of palm olein-olive oil blends. Journal of Food Agriculture and Environment, 8, 175-178.

Oke, E. K., Idowu, M. A., Sobukola, O. P., Adeyeye, O. P., \& Akinsola, A. O. (2018). Frying of food: a critical review. Journal of Culinary Science \& Technology, 16(2), 1-21.

Osawa, C. C., \& Gonçalves, L. A. G. (2012). Deep-fat frying of meat products in palm olein. Food Science and Technology, 32(4), 804-811. http://dx.doi.org/10.1590/S0101-20612012005000109.

Park, J. M., \& Kim, J. M. (2016). Monitoring of used frying oils and frying times for frying chicken nuggets using peroxide value and acid value. Korean Food Science of Animal Resources, 36(5), 612-616. http://dx.doi.org/10.5851/kosfa.2016.36.5.612. PMid:27857536.

Rivera, Y., Gutiérrez, R., Gómez, R., Matute, M., \& Izaguirre, C. (2014). Quantification of the deterioration of vegetable oils used in frying processes in establishments located in the Libertador Municipality of the State of Merida. Ciencia e Ingeniería, 35, 157-164.

Rudzińska, M., Hassanein, M. M., Abdel-Razek, A. G., Kmiecik, D., Siger, A., \& Ratusz, K. (2018). Influence of composition on degradation during repeated deep-fat frying of binary and ternary blends of palm, sunflower, and soybean oils with health-optimized saturated-to-unsaturated fatty acid ratios International. Journal of Food Science and Technology, 53(4), 1021-1029.

SAS Institute. (2006). American multinational developer of analytics software v. 9. North Carolina: SAS Institute.

Sayon-Orea, C., Carlos, S., \& Martínez-Gonzalez, M. A. (2015). Does cooking with vegetable oils increase the risk of chronic diseases? a systematic review. British Journal of Nutrition, 113(S2), S36-S48.

Sharoba, A. M., \& Ramadan, M. F. (2012). impact of frying on fatty acid profile and rheological behaviour of some vegetable oils. Journal of Food Processing \& Technology, 3(7), 1-10.

Tarmizi, A. H. A., \& Ismail, R. (2014). Use of pilot plant scale continuous fryer to simulate industrial production of potato chips: Thermal properties of palm olein blends under continuous frying conditions. Food Science \& Nutrition, 2(1), 28-38. http://dx.doi.org/10.1002/ fsn3.76. PMid:24804062.

Tirado, D. F., Acevedo, D., \& Guzmán, L. E. (2012). Food deep frying. Revisiones de la Ciencia, Tecnología e Ingeniería de los Alimentos, 12(1), 70-82.

Torres, F., \& Rojas, A. (2018). Obesity and public health in Mexico: transformation of the hegemonic pattern of food supply-demand. Revista Problemas del Desarrollo, 49(193), 145-169.

Yu, K. S., Cho, H., \& Hwang, K. T. (2018). Physicochemical properties and oxidative stability of frying oils during repeated frying of potato chips. Food Science and Biotechnology, 27(3), 651-659. http://dx.doi. org/10.1007/s10068-017-0292-y. PMid:30263791. 